\title{
Basic Derivatives for the OIl and Gas Company
}

\author{
MARK R. SMITH*
}

This article provides a general overview of some of the basic derivatives available 10 oil and gas companies. The author begins by defining what a derivative is and briefly summarizing four basic kinds of derivatives. The author offers other examples of derivative products and illustrates how oil and gas companies can design and utilize these products to meet their individual needs. The article includes a discussion of the ISDA master agreement, which is used for most over-the-counter derivative contracts. As well, the article outlines some of the key regulatory provisions governing and affecting derivatives, with particular emphasis on Alberta.
Cet article donne un aperçu des dérivés de base disponibles aux entreprises pétrolières et gazières. $L$ 'auteur commence par donner la définition d'un dérivé, suivie d'un court résumé de quatre grandes sortes de dérivés. L'auteur cite d'autres exemples de sous-produits et démontre comment les entreprises pétrolières et gazières peuvent concevoir et utiliser ces produits pour répondre à leurs besoins individuels. L'article comprend une discussion de l'Accord-cadre de I'ISDA qui est utilisé dans la plupart des cas de contrats de dérivés gré à gré. De plus, l'article donne les grandes lignes de certaines dispositions réglementaires clés régissant et touchant les dérivés, particulièrement en Alberta.

\section{TABLE OF CONTENTS}

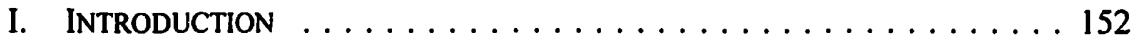

II. WHAT IS A DERIVATIVE INSTRUMENT? $\ldots \ldots \ldots \ldots \ldots \ldots \ldots 153$

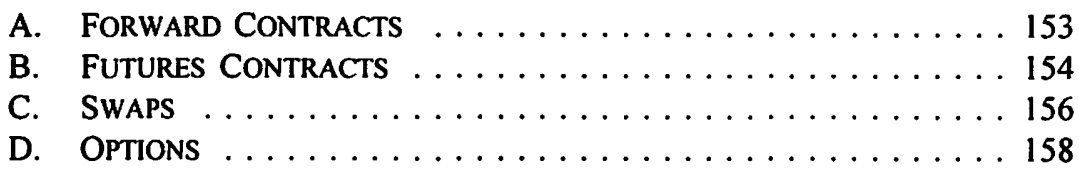

III. Derivative Products and Trading Strategies $\ldots \ldots \ldots \ldots 160$

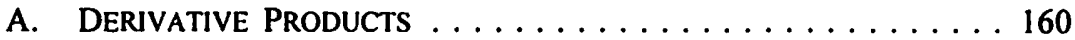

B. Derivative Trading Strategies $\ldots \ldots \ldots \ldots \ldots \ldots \ldots 161$

IV. MARKET PARTICIPANTS $\ldots \ldots \ldots \ldots \ldots \ldots \ldots \ldots \ldots \ldots \ldots$

V. OTHER HEDGING TRANSACTIONS $\ldots \ldots \ldots \ldots \ldots \ldots \ldots \ldots \ldots$

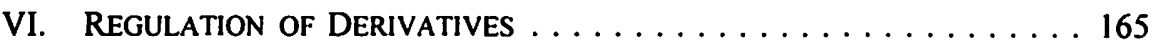

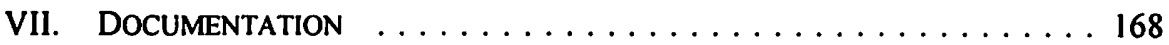

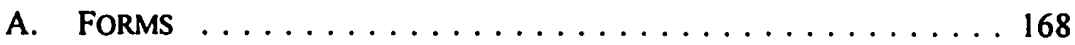

B. ISDA 1992 MASTER AGREEMENT $\ldots \ldots \ldots \ldots \ldots \ldots \ldots$

VIII. BANKRUPTCY AND INSOLVENCY $\ldots \ldots \ldots \ldots \ldots \ldots \ldots \ldots 173$

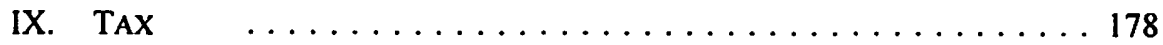

X. CONCLUSION .................... 178

\section{INTRODUCTION}

The principal outputs from oil and gas production companies; namely, oil, gas, and natural gas liquids, are fungible commodities whose prices are largely determined by world markets. Given that a producer is unable to determine the price for its products, the producer's profitability will fluctuate with the market price for its commodities. While the cyclical nature of the markets for oil and gas products provides excitement, it also renders

B. Comm., LL.B. Partner, Osler, Hoskin \& Harcourt LLP, Calgary, Alberta. I wish to thank David Caplan of Oslers for his assistance in the preparation of this article. 
more difficult the planning, budgeting, and implementation of producer growth strategies. The controlled use of derivative products and trading strategies to effectively create a more stable and predictable commodity price can provide increased comfort to lenders and equity investors, thereby contributing to the enterprise value of an otherwise risk-exposed oil and gas producer.

This article will examine generally the regulatory and contractual framework applicable to derivatives that are commonly used by Canadian oil and gas producers.

\section{WhAT IS A DERIVATIVE INSTRUMENT?}

A derivative has been defined as:

a financial instrument, traded on or off an exchange, the price of which is directly dependent upon (i.e. "derived from") the value of one or more underlying securities, equity indices, debt instruments, commodities, other derivative instruments, or any agreed upon pricing index or arrangement (e.g. the movement over time of the consumer price index or freight rate). Derivatives involve the trading of rights or obligations based on the underlying product, but do not directly transfer property. They are used to hedge risk or to exchange a floating rate of return for fixed rate of return.'

There are numerous derivative products with a vast array of names. However, each is constructed using a combination of one or more of the four basic derivative instruments; namely, (i) the option, (ii) the swap, (iii) the forward contract, and (iv) the futures contract. $^{2}$

These basic instruments can be combined and packaged in a number of different ways to achieve specific hedging or speculation goals.

\section{A. FORWARD CONTRACTS}

A forward contract is an individually negotiated agreement by which a commercial buyer and seller agree upon the purchase and sale of a specified quality and quantity of an underlying asset (the "Underlying") at a specified future date. A price ("exercise price") may be agreed upon in advance, or there may be agreement that the price will be determined at the time of delivery. Among other possibilities, the Underlying may be an agricultural commodity, a currency, an equity or equity index, or an interest rate.

The forward agreement may be settled either by a physical delivery of the Underlying or by a cash settlement of the difference between the current market ("spot") price of the Underlying and the exercise price. Because no cash or Underlying is exchanged until maturity of the forward contract, the parties are each exposed to the risk ("credit risk") that the other party ("counterparty") to the agreement will default on its obligations at maturity. 


\section{B. FUtURES CONTRACTS}

A futures contract is an "exchange-traded, standardized agreement to purchase or sell a commodity for delivery in the future: (1) at a price that is determined at initiation of the contract; (2) which obligates each party to the contract to fulfil the contract at the specified price; (3) which is used to assume or shift price risk; and (4) which may be satisfied by delivery or offset." ${ }^{3}$ The Securities Act (Alberta) defines a futures contract as "the obligation to make or to take future delivery of (i) a commodity, (ii) a security, or (iii) cash if the amount of cash is derived from, or by reference to, a variable, including (a) a price or quote for a commodity or security, (b) an interest rate, (c) a currency exchange rate, or (d) an index or benchmark."

A futures contract is essentially a forward contract whose terms have been standardized and which is traded on an exchange. These characteristics make a futures contract much more liquid than a forward contract. As well, a futures differs from a forward in that a futures trader must post with the futures clearinghouse a performance bond ("margin") before the contract can be entered into and then must post subsequent "maintenance margin" funds as required. The margin account is drawn upon or added to by the clearinghouse as required to enable daily settlement ("marking to market") of the amount the spot price of the Underlying falls short of or exceeds the exercise price of the futures. This daily marking to market ensures that amounts payable by either party to the contract at any time during the life of the contract are relatively small. ${ }^{5}$ The combination of upfront delivery of margin funds by each party to the futures contract, the daily marking to market of their margin accounts, and the intermediation of a third party clearinghouse with its own cash reserves, together effectively eliminate credit risk from futures contracts. $^{6}$

The distinction between futures and forwards is material in the United States where forward contracts are exempt from regulation on the basis that the Commodity Exchange $A c t^{7}$ was not intended to regulate trades of commodities in the ordinary course of business by the producers and users of such commodities. In the United States, futures contracts are regulated pursuant to the Commodity Exchange Act, and the Commodity Futures Trading Commission ("CFTC") has the exclusive jurisdiction to regulate options and futures contracts. ${ }^{8}$ As will be discussed below, forward contracts in Canada are also

CFTC Glossary, supra note 1.

Securities Act, S.A. 1981 c. S-6.1, s. 1(h.01) as am. by Securities Amendment Act, S.A. 1999, c. C15, s. 2(e) [hereinafter Securities Act].

Chance, supra note 2 at 244-46.

Ibid. at 5.

7 U.S.C. $\$ \S 1-25$ (1994).

The difference between a physical contract and a financial contract is very relevant in determining whether or not the contract is an forward sale or a futures contract governed by the Commodity Exchange Act. See, for example, MG Refining and Marketing, Inc. and MG Futures Inc. where the CFTC stated as follows in determining that a contract with physical delivery provisions was an illegal futures contract:

These contracts ... contain all the essential elements of a futures contract: they call for the making or taking of delivery of a commodity in the future at a price or pricing formula established at initiation; they may be satisfied either by delivery of the commodity or by engaging in an offsetting transaction without delivery; the purpose of the transaction is 
generally exempt from regulation, while futures are generally characterized as securities and are therefore subject to the provincial securities acts.

\section{USES OF FUTURES}

Natural gas futures trade on the New York Mercantile Exchange ("NYMEX"). Each futures contract represents one trading unit of 10,000 million British thermal units (MMBTU) delivered at Henry Hub in Louisiana for a specified one month period. The specifications for the natural gas are such as to meet the applicable pipeline specifications at the time of delivery. The delivery period for each trading unit commences on the first calendar day of the delivery month and must be completed by the last calendar day of that month, and deliveries are to be made as uniformly as possible on an hourly and daily basis.?

An oil futures contract represents one trading unit of 1,000 US barrels which are to be delivered rateably over the course of a month at Cushing, Oklahoma. Various grades of crude are traded, including West Texas Intermediate, Low Sweet Mix, New Mexican Sweet, North Texas Sweet, Oklahoma Sweet, and South Texas Sweet. Certain foreign crudes are also traded, subject to specified price adjustments.

While these NYMEX traded contracts may be satisfied by physical delivery, 95 percent are closed prior to settlement by entering into an opposite transaction. ${ }^{10}$ For example, a party that is short one oil trading unit for the month of June (i.e., that party has sold a futures contract and has thereby agreed to deliver 1,000 US barrels of crude during the month of June) can merely purchase a trading unit for June, prior to the end of May, to close its short position. The long and short units are set off against each other by the clearinghouse, and the resulting net position is zero (i.e., no oil or payment to be delivered in June).

Futures contracts are a prime hedging tool for producers, since producers are naturally long in the commodities which they produce. By selling a futures contract, the producer has committed to selling a specified commodity at a specified price at a specified time in the future, thereby creating selling price certainty for the amount of commodity represented by the futures contract. Similarly, an end user of the commodity will buy futures to obtain purchase price certainty for its input materials.

Just as buying and selling futures can be an effective means of hedging price risk, so can the execution of forward contracts which are entered into with the same effect either directly or through an intermediary. However, in contrast to futures, forward contracts can be customized to fit to the hedging programs desired by the counterparties involved."

primarily to speculate or hedge the risk of price change in the commodity without actually acquiring the underlying commodity.

This discussion of the exchange is based on the New York Mercantile Exchange publication How the Exchange Works, online: The New York Mercantile Exchange <http://www.nymex.com> (date accessed: May 2000) (hereinafter NYMEX].

W.D. Herrington, "International Refining and Hedging of Mineral Products" (1997) 43 Rocky Mtn.

Min. L. Inst. 11-1 at 11-23.

NYMEX, supra note 9. 
While the vast majority of futures contracts traded on NYMEX are not actually settled in kind, it is important for the terms of the contracts to provide for actual delivery, in order to ensure that the relationship between futures prices and spot prices continues to hold. $^{12}$

\section{SWAPS}

Swaps (or "contracts for differences") are individually negotiated transactions in which each counterparty to the swap agrees to exchange periodic cash flows based on differences over time in the state of one or more specified Underlyings. The Underlying(s) in a swap could be market indexes, currencies, interest rates, or some other specified asset or liability. Swaps can relate to different Underlyings, or to the same Underlying at different places or at different times and are most often structured in connection with interest rates and currency exchange rates. A swap agreement is conceptually the same as a series of forward contracts, the primary difference between the two products being that a swap features less credit risk because there are more frequent settlements of cash flows between the parties during the life of the agreement. ${ }^{13}$

\section{INTEREST RATE SWAPS}

A very common swap agreement involves the exchange of the cash flows that are attributable to a floating interest rate, for the cash flows that are attributable to a fixed interest rate ("fixed for floating" swap). A typical interest rate swap will set out a principal amount to which the fixed and floating interest rates both apply (referred to as the "notional amount"), the dates on which the swap begins and ends, details of the rates to be swapped, and the dates on which the settlements of net cash flows are to take place during the life of the swap. The fixed rate payer will on specified settlement dates be liable to pay to the floating rate payer an amount which is equivalent to the fixed rate of interest on the notional amount since the last settlement date. On those same dates, the floating rate payer will be liable to pay the fixed rate payer the amount of interest payable on the notional amount at the specified floating rate since the last settlement date. The floating rate can be a variety of rates but is often a LIBOR ${ }^{14}$ based rate.

The amounts payable by each counterparty to the other are netted off, and the counterparty which owes the most pays the net amount to the other. Thus, if the floating rate amount payable exceeds the fixed rate amount payable, the floating rate payer will simply pay to the fixed rate payer the difference between the two amounts. Similarly, if the floating rate amount payable is less than the fixed rate amount payable, the fixed rate payer will pay the difference between those two amounts. ${ }^{15}$ 


\section{BASIS SWAPS}

Another type of swap agreement is a basis swap. "Basis" is the difference in price or yield between two locations, instruments, time periods, indices, or other variables. Basis may reflect different time periods, product forms, qualities, or locations. Most gas producers are familiar with and execute physical swaps, in which one party delivers gas at one location in exchange for the other party delivering the same quantity of gas at another location. If a financial hedge is desired against the widening of a price differential between two locations, a basis swap could be executed.

For example, suppose that a gas purchase contract is based on NYMEX pricing (which itself is based on natural gas being delivered at Henry Hub, Louisiana) but the physical gas is delivered to the Nova System for transfer within the Nova Inventory Transfer ("NIT") system. The "basis" is the differential between the prices for delivery at Henry Hub and delivery at the AECO "C" storage hub. This differential is not constant, and the potential detrimental change in the differential is referred to as basis risk. In a basis swap, the producer agrees to pay the counterparty the amount by which the basis differential becomes less than some specified amount, in exchange for the counterparty paying the producer the amount that the differential exceeds the specified amount (all of which is of course based upon a specified volume of natural gas) (see Fig. 1).

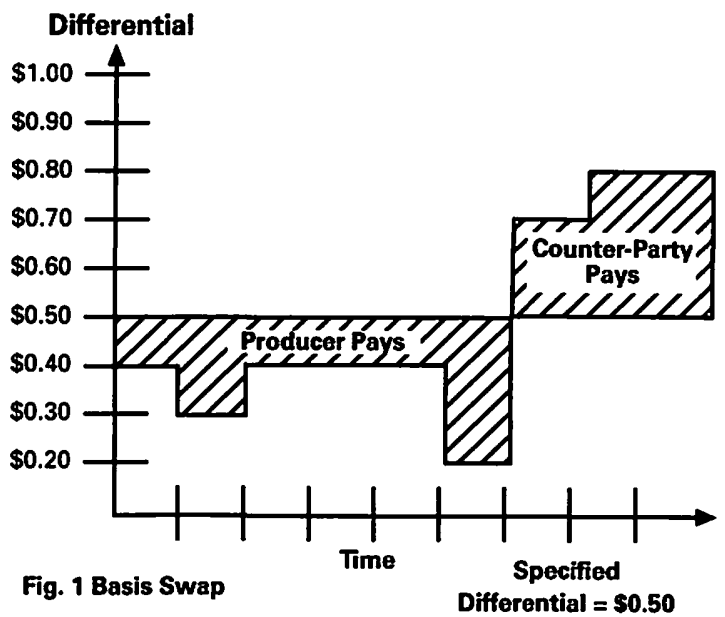

Another common example of a basis swap is a swap of interest rates based on different time periods, such as swapping the three month LIBOR rate with a six month LIBOR rate. ${ }^{16}$

As a further example of a basis swap, consider that jet fuel is a commodity that is not traded on the NYMEX. Accordingly, an airline that wishes to hedge its fuel costs has to look to other products as the Underlying for a financial derivative. Since the price of jet fuel is relatively closely correlated to the price of heating oil, an airline can buy heating 
oil futures contracts (refer to above futures discussion) in order to roughly hedge the price of the jet fuel that it intends to actually acquire. However, since heating oil trades independently of the price of jet fuel, the airline would not be perfectly hedged against a rise in the price of jet fuel. Therefore, the airline will seek to hedge the risk of unfavourable changes in the differential between the prices of heating oil and jet fuel. The airline could accomplish this by entering into an appropriately designed basis swap with a counterparty that wishes to hedge against an opposite movement in the basis.

\section{OPTIONS}

Options can be divided into two categories: an option to sell (a "put") and an option to purchase (a "call").

\section{CALLS}

A call gives the holder of that option the right but not the obligation to purchase a specified Underlying at a specified time, place, and price. The seller (or "writer") of the call has the obligation to sell the Underlying on the terms specified if and when the holder of the call exercises his option. ${ }^{17}$

An example of the mechanics of a call option is as follows. Party A agrees to write a call permitting the holder (Party B) to buy a barrel of West Texas Intermediate Oil ("WTI") at Cushing, Oklahoma for a price of $\$ 25$ at any time within the next thirty days. The buyer of the option will pay a fee ("premium") for the option. If the price of a barrel of WTI oil at Cushing, Oklahoma trades at a price of, for example, \$28 sometime before expiry of the option, then the holder of the call can exercise the option at that time and require the writer to deliver a barrel of oil at a price of $\$ 25$. The holder can then sell the delivered oil at the spot market price of $\$ 28$ for a net profit of $\$ 3$ less the premium that was paid for the option. However, if the spot price of WTI remains below ( $\$ 25$ plus premium) throughout the term of the option, then the call will expire unexercised (see Fig. 2).

\section{PUTS}

A put gives the holder of that option the right but not the obligation to deliver for sale a specified underlying commodity, instrument or other asset (referred to as the "Underlying") at a specified time, place, and price. The seller (or "writer") of the put has the obligation to purchase the Underlying on the terms specified if and when the holder of the put exercises his option. ${ }^{18}$

The inverse of the call's mechanics applies to a put option. Using the above WTI example, if a put were written with an exercise price of $\$ 25$, and if the price of the oil fell to $\$ 22$, then the option would be "in the money" (could be exercised at a profit to the option holder); the holder of the option could therefore exercise the put and deliver the 
Underlying (the oil) to the put writer in exchange for the agreed price of $\$ 25$, for a net profit to the put holder of $\$ 3$ less the option's premium (see Fig. 3).

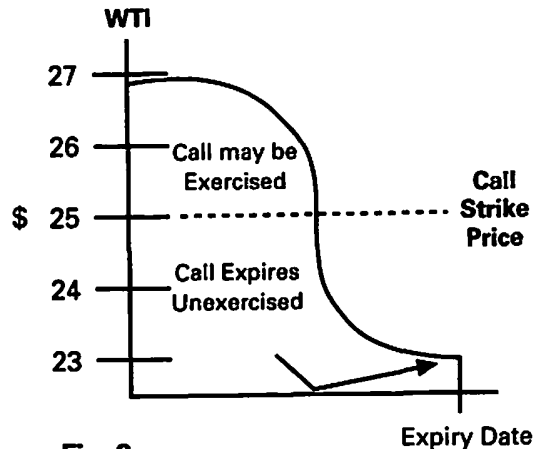

Fig. 2

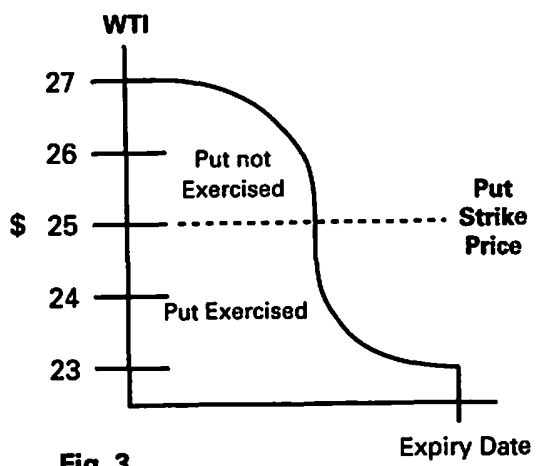

Fig. 3

\section{TERMS OF EXERCISE}

Options are often referred to as either American style or European style. An American style option can be exercised at any time up to its expiry date, whereas a European option can only be exercised on its expiry date. ${ }^{19}$ While a portfolio of European options with successive expiry dates could conceivably be purchased to effectively replicate a single American style option, the greater flexibility of the latter style is evident. Not surprisingly, a "Bermuda" option falls somewhere between the American and European styles, allowing exercise only on specified, non-contiguous dates. ${ }^{20}$ For their part, "Asian options" feature an exercise price which is determined during the life of the option and equals the average spot price of its Underlying over a specified time period. ${ }^{21}$

For all types of options, the Underlying is generally not delivered upon exercise of the option. Rather, the option writer pays to the option holder the amount by which the spot price of the Underlying at the time of exercise either exceeds (in the case of a call) or falls short (in the case of a put) of the exercise price.

\section{USES OF OPTIONS}

For a producer, the purchase of a put enables it to protect ("hedge") its product revenues against falling commodity prices. A fee ("premium") is paid for the put by the producer in exchange for the opportunity to reduce or eliminate its downside price risk. The purchase and sale of a customized combination of derivative instruments, however, enables the engineering of a more desirable payoff function. For example, a producer could offset the cost of the premium paid for a put by concurrently selling one or more calls at a higher exercise price. This strategy is often referred to as a "collar." A costless collar results when the premium paid for the put is entirely offset by the premium 
received by writing the call(s). In any collar strategy, the producer sacrifices some of its upside price potential in exchange for its cheaper downside price protection. ${ }^{22}$

\section{Derivative Products and Trading Strategies}

\section{A. Derivative Products}

From the four basic derivative instruments of forwards, futures, swaps, and options, a cornucopia of more sophisticated derivative products can be developed, limited only by the imagination. Derivative products are individually negotiated and may include combinations of publicly traded derivatives and privately negotiated derivatives (the latter of which are often termed "OTC" or over-the-counter derivatives), as well as derivatives with special provisions (also known as "exotic" derivatives).

Exotic derivatives generally provide special options or restrict the exercise of the derivative instrument. Exotic derivatives may include such features as barriers, average strike or average rate options (also known as Asian options), and chooser options, among others. ${ }^{23}$ Barrier options are options whose exercise depends on the price of the Underlying overcoming a specified "barrier." This barrier can either be a "knock-in", meaning that the price has to hit the barrier for the option to become effective, or it can be a "knock-out" whereby the option becomes ineffective once the barrier price has been reached. For example, a put option with an exercise price of $\$ 25$, but specifying that the price of the Underlying must decrease to $\$ 23$ prior to the option becoming effective, is a knock-in option. Once "knocked-in" (or effective), the put may be exercised for $\$ 25$ (see Fig. 4(a)). A producer may choose to purchase this type of a put to reduce the premium payable on the put while taking advantage of high expected price volatility in the Underlying. Conversely, the option could be structured as a knock-out option whereby, in our previous example, the option would terminate if the price of the Underlying fell to $\$ 23$ (see Fig. 4(b)).
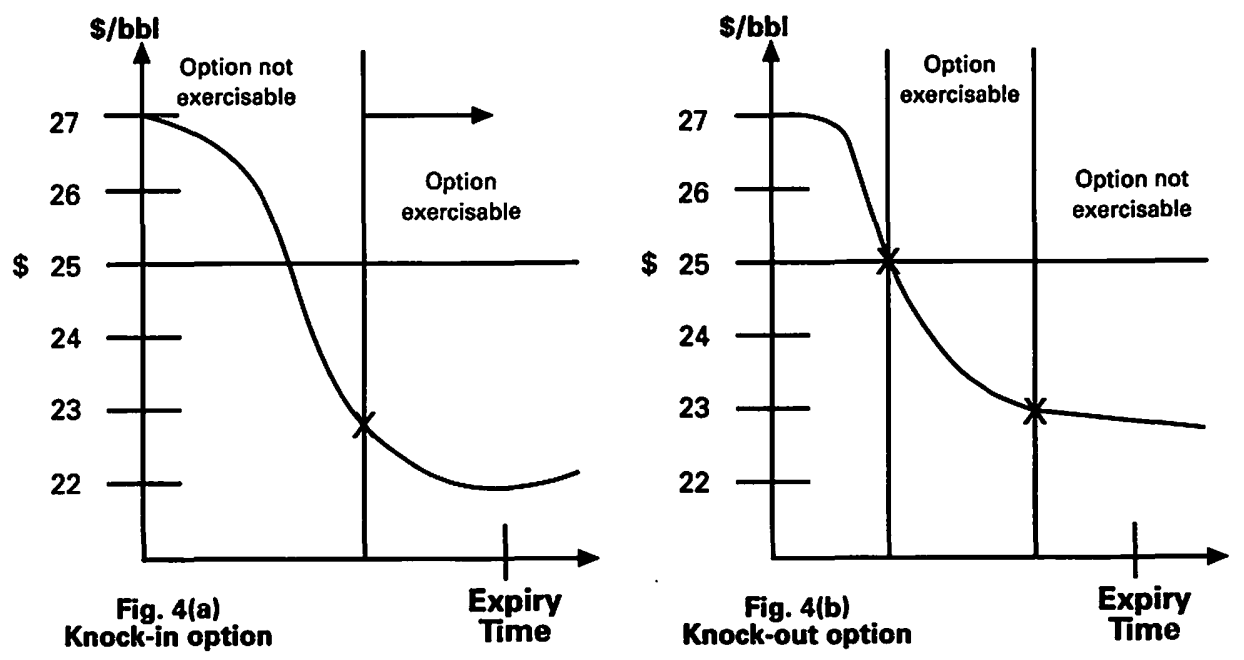
An option can also be structured as a double knock-in or double knock-out, whereby it must reach a certain level twice for the option to become effective. An option could alternatively feature both a knock-in and a knock-out, and other combinations are obviously possible as well. Yet another example of the diversity of possible derivative products, a "chooser" option, enables the option holder to chose at any time in the life of the option whether it will be a call or a put. ${ }^{24}$

Another common derivative product is the option to enter into a specified swap agreement at any time until the expiry of the option: this type of product is appropriately termed a "swaption." A swaption gives the holder the opportunity to wait and determine at any time before the option's expiry whether it still wishes to enter into the swap or whether spot prices have changed to a point that it is best to simply let the swaption expire worthless. ${ }^{25}$

\section{B. Derivative Trading StRategies}

Derivative products can be combined in a customized manner to best match the hedging requirements of the trader. A good example of this is an airline's purchase of heating oil futures and a basis swap to hedge against possible increases in the cost of jet fuel. Another popular combination is the collar, which gives its purchaser a party downside price protection (a "floor") for little or no net premium cost, in exchange for a truncated price upside (a "cap").

For example, if WTI Oil is currently trading at $\$ 26$ and a producer desires to avoid future prices below $\$ 24$, the producer could buy a put with an exercise price of $\$ 24$. There of course would be a premium to be paid to acquire the put. To create a costless (or low cost) collar, the producer would simultaneously write one or more calls with an exercise price of, for example, $\$ 27$, and the premium received for writing the calls would offset (or at least subsidize) the premium paid for the put. The call's exercise price (\$27) would form the cap, and the put's exercise price (\$24) would form the floor, on the range of prices that the producer will receive on the WTI that is covered by the collar (see Fig. 5). The relative levels of the cap and the floor to the desired sale price of WTI would vary depending on market conditions and on the options that are used to construct the collar. An end user of the commodity in question would want to execute the opposite transaction: it would purchase a call to limit its exposure to rising prices and, to offset the premium cost of the call, it would also sell a put. This would sacrifice some of its upside potential should the commodity price decline during the life of its options. 


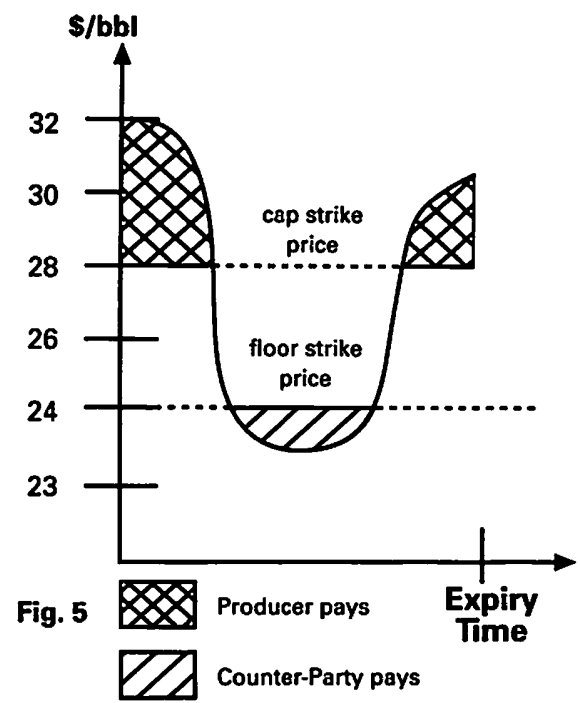

Conceptually, a collar is similar to a single period swap with the primary exception being that the purchaser of a collar can experience unhedged price fluctuations within the range defined by the cap and floor of the collar. By contrast, a counterparty to a swap will receive exactly the swapped price of the commodity for the term of the swap. As well, whereas collars are created by the purchase and sale of instruments which are traded on commodity exchanges, swaps are individually negotiated and therefore do not feature the same price transparency or ease of reversal. It should also be noted that a producer which is unwilling to sacrifice all of the price upside beyond the level of the collar's cap could instead enter into a "participating collar" or a "participating swap" where the price cap would become graduated rather than constant.

Other combinations of options include straddles, strips, and straps. A "long straddle" consists of the purchase of both a call and a put having identical exercise prices and expiry dates. The purpose of a straddle is to exploit price volatility in the Underlying which exceeds market expectations. Conversely, a "short straddle" (consisting of writing a call and a put, both having the same exercise price and expiry date) is used to exploit price volatility that falls short of market expectations. If the spot price of the Underlying upon exercise of the options is sufficiently above or below the exercise price of the straddle's options to exceed the total premiums paid for those options, then the straddle holder will realize a net gain on the trading strategy. ${ }^{26}$

Strips and straps are merely variations of the straddle where instead of buying only one call and one put, the producer purchases either two puts to the one call (a "strip") if it believes that a price decrease is more likely, or purchases two calls to the one put (a "strap") if it believes that it is more likely that the price will increase. By combining a variety of derivative products, a payoff function can be created that hedges the producer against volatility in a number of factors which affect the sale price of its output (including even the weather as will be discussed later in this article). 


\section{MARKET PARTICIPANTS}

A hedger is a party, such as a producer or end user of commodities, which desires to reduce or eliminate the risk of a detrimental change to the spot (or current) price of a commodity that it expects to produce or need in the future. For example, a natural gas hedger has been defined as

a person or company who carries on agricultural, mining, forestry, processing, manufacturing or other commercial activities, and, as a necessary part of these activities, becomes exposed from time to time to a risk attendant upon fluctuations in the price of gas and upsets that risk through trading in gas contracts whether or not any particular trade is affected for that purpose. ${ }^{27}$

Hedgers generally attempt to stabilize costs or revenues by establishing an offsetting position (either long or short) in the Underlying. Speculators, by contrast, attempt to profit from changes in spot prices by (1) receiving derivative product premiums and/or (2) buying low and selling high. ${ }^{28}$ Speculators take a position in the financial markets that magnifies rather than reduces their total risk exposure. In the process, speculators assume the risk that hedgers are trying to avoid. There is some debate as to the optimal number of speculators for a healthy derivatives market, but while it is clear that hedgers themselves generate a market in many derivative products, other products rely on the additional participation of speculators to generate liquidity. ${ }^{29}$

Consider, for example, a collar for natural gas. A producer's revenue and profit are directly dependent upon the price of its gas that it sells, whereas an end user's profit is in an inverse relationship with the price of the gas that it consumes. An end user is a natural fit to be on the other end of the producer's collar transaction: the end user desires to buy the call in order to limit its exposure to rising gas prices, and it likewise desires to write the put in order to generate premium income in exchange for the risk of being obligated to purchase gas at the put's exercise price (which is invariably lower than the current spot price). Since the producer and the end user are willing to execute opposing trades, they naturally generate liquidity for this derivative product.

On commodity exchanges such as the NYMEX, liquidity is generated by the traders (hedgers and speculators) and brokers who trade in the various product markets. ${ }^{30}$ In the over-the-counter (OTC) market, liquidity is generated by intermediaries such as financial institutions and commodity marketers, although a trade may also be negotiated and executed between parties directly, without such intermediation. If necessary, an intermediary will match different combinations of trading parties, or combine exchangetraded derivatives with OTC derivatives to accomplish the desired trading strategy.

In the event that no trader can be found that is willing to accept the counterparty position for a particular derivative product (i.e., where a natural gas consumer desires a 
basis swap for natural gas prices between Dawn, Ontario and Sumas, Washington), an intermediary may become the counterparty and then enter into a variety of contracts with other traders to reduce or eliminate the intermediary's net basis risk exposure. In our example, the intermediary could execute a series of basis swaps with a number of counterparties such as (i) between Sumas and AECO "C", (ii) AECO "C" and NYMEX, and (iii) NYMEX and Dawn so as to offset its initial Dawn-Sumas basis swap. Intermediaries have accordingly developed sophisticated programs which manage on a continuing basis the net risk exposure of their derivative portfolios.

An intermediary may even create a market by taking a position for its own account. An interesting illustration of an intermediary generating liquidity in a new derivative product is the weather risk management program offered by Enron Corp. ${ }^{31}$ Utility energy companies are provided with the opportunity to purchase "degree day" swaps and collars which will hedge their revenues in the event of an unusually mild winter or cool summer. These derivative products, which can conceivably be based on any measurable weather characteristic such as degree days or inches of rainfall, permit a purchaser of the product to offset its decreased revenues by means of cash received under the terms of the derivative product. Of course, the offsetting products that Enron seeks to market are pitched to end users of electric power who may wish to hedge against the increased power consumption associated with unusually cold winters or hot summers. Among many other potential users of these weather based derivatives, agricultural companies can use them to replenish revenues which would otherwise be lost due to freezing or drought, and insurance companies can use them to reduce exposure to claims resulting from high rainfall or other weather related causes. ${ }^{32}$

\section{Other hedging Transactions}

Financing can be designed to hedge against price fluctuations in a producer's output, through the use of such products as commodity priced loans and prepaid forward contracts. In a commodity priced loan, the repayment schedule for the loan is tied to the price of the relevant commodity: as the commodity price (and therefore revenue) decreases, the required amount of payment on the outstanding balance of the loan also decreases, providing a natural hedge to changes in the commodity price.

Prepaid forward contracts, which are similar to volumetric production payment structures, provide for an upfront payment in exchange for the delivery of a specified volume of commodity over a period of time to satisfy the resulting obligation. In the United States, volumetric production payments are carved out of the oil and gas interest and do not form part of a bankrupt's estate, which allows this type of structure to work where the creditworthiness of the grantor is an issue. However, the financier in those circumstances still incurs reserve risk.

Whereas Canadian land registration and income tax laws do not lend themselves to volumetric production payments, they do permit prepaid forward contracts. Generally, the

3 Enron North America, Weather Risk, online: Enron North America <http://www. ect.enron.com/products/weather/main/fset.html> (date accessed: 14 March 2001). 
obligation to deliver the specified volumes of a commodity, often natural gas, is a secured corporate covenant. Security for performance of this obligation may include an encumbrance on the reserves from which the product was intended to be delivered, but may include other corporate assets. Since the obligation to deliver is a corporate covenant, the volumes are required to be delivered at a particular delivery point without regard to their source, and the force majeure exemption is not applicable. A prepaid forward contract provides a natural hedge for the producer because it fixes the commodity price in advance of delivery, protecting from time spot prices that may have changed considerably.

\section{Regulation OF DeRivatives}

In Canada financial derivatives are regulated by the various securities commissions for each province. The Alberta Securities Act defines a "security" to include (among a long list of other items), "any item or thing ... that is a futures contract or option but is not an exchange contract." $\mathrm{A}$ futures contract is defined as

any obligation to make or take future delivery of

(i) a commodity,

(ii) a security, or

(iii) cash if the amount of cash is derived from, or by reference to, a variable, including

(A) a price or quote for commodity or security,

(B) an interest rate

(C) a currency exchange rate, or

(D) an index or benchmark,

but does not include an obligation or a class of obligations that is designated not to be a futures contract pursuant to an order made under section 9.1.".

An exchange contract is defined as

a futures contract or an option where (i) its performance is guaranteed by a clearing agency, and (ii) it is traded on an exchange pursuant to standardized terms and conditions set forth in the by-laws, rules or regulations of that exchange at a price agreed on when the futures contract or option is entered into on the exchange, and includes any instrument or class of instruments that (iii) meets the requirements referred to in subclauses (i) and (ii), and (iv) is designated as an exchange contract by an order of the Commission. ${ }^{35}$

Exchange contracts are regulated under Part 7.1 of the Securities Act which provides that trading in an exchange contract is prohibited unless the exchange is recognized by the Commission, regardless of the exchange's geographic location. There are approximately thirty-two exchanges outside of Alberta that are recognized for this purpose including the NYMEX, the International Petroleum Exchange of London Ltd., the Chicago Board of 
Trade, and the Kansas City Board of Trade as well as the main securities exchanges. ${ }^{36}$ Consequently, exchange contracts are dealt with outside of the Securities Act and are governed instead by the rules of the various exchanges that the particular exchange contracts trade.

Most of the hedging done by the oil and gas industry does not involve publicly traded derivative products, but rather OTC products which are negotiated specifically for each user. In Alberta, provided that certain conditions are met, OTC derivatives and commodity contracts are excluded from the definition of a "security" and are therefore exempt from the provisions of the Securities Act. ${ }^{37}$ An OTC derivative is defined in the exempting order as follows:

an option, a forward contract, a contract for differences or other instruments of a type commonly considered to be a derivative, or any combination of any of them, where

4.1(a) the agreement relating to, and the material economic terms of, the option, forward contract, contract for differences or other instruments having been customized to the purposes of the parties to the agreement and the agreement is not part of a fungible class of agreements that are standardized as to their material economic terms,

(b) the creditworthiness of a party to the agreement would be a material consideration in entering into or determining the terms of the agreement, and

(c) the agreement is not entered into or traded on or through an organized market, stock exchange or futures exchange and is not cleared by a clearing corporation; or

4.2 such option, forward contract, contract for differences or other instrument is not an exchange contract or commodity contract and would not be a security but for paragraph (xvi) of the definition of "security" in subsection $i(v)$ of the Act; and ...

for the purposes of this order "commodity contract" means a contract that contains an obligation to make or take future delivery of a commodity, which contract is not an OTC derivative and which contract may include an option for cash settlement. ${ }^{38}$

\section{The Order exempts:}

(a) an OTC derivative of which the underlying interest consists of an interest rate, Canadian or foreign currency, a foreign exchange rate, a commodity, a security, an index, a benchmark, or other variable, or another OTC derivative or some relationship between, or combination of, one or more of them; or (b) a commodity contract ${ }^{39}$ contracts (1992), A.S.C.S. 300. 
provided that the transactions are between "Qualifying Parties."

Qualifying Parties are listed in the Order and include banks, commercial users (which includes producers and end users), insurance companies, sophisticated entities, individuals having a net worth of at least $\$ 5$ million (excluding principal residence), companies having total assets in excess of $\$ 25$ million, brokers, and investment dealers.

Importantly, also exempt are "contract[s] for the sale or exchange of a commodity that provide for the physical delivery only of the subject matter of the contract." physical delivery contracts do not have to be between "Qualifying Parties" to be exempt, reflecting an intention by the Alberta government to abstain from regulating contracts for future delivery which are executed in the ordinary course of business by participants in the various "industrial, commercial and business sectors." 41

Ontario is moving in the same direction. The Ontario Commodity Futures Act ${ }^{42}$ governs exchange-traded derivatives. The Ontario Securities Commission has recently proposed Rule 91-504 to govern OTC derivatives. ${ }^{43}$ The proposed Rule was similar in approach to the Alberta Order, in that it exempt OTC derivatives which are entered into by qualifying parties. However, the Rule has not been adopted by the Ontario government.

A similar approach is used in the United States, where the exchange trading of commodities has been governed by the Commodity Exchange Act since 1935. ${ }^{44}$ The Commodity Futures Trading Commission ("CFTC"), formed in 1974, licenses exchanges and promulgates rules and regulations in respect of those exchanges. The Act prohibits the over-the-counter trading of a contract for the "purchase or sale of a commodity for future delivery," 45 referred to as a futures contract. However, "forward sales" are permitted, which are defined as contracts providing for the "sale of a cash commodity for deferred shipment or delivery." 46

Unfortunately, this wording does not make it absolutely clear whether the future sale of a product is a futures contract, and therefore regulated under the Commodities Exchange Act, or merely a forward contract which is exempt from the Act. The CFTC has issued a number of decisions and statutory interpretations that attempt to clarify what is included in a forward contract. ${ }^{47}$ Generally, contracts providing for physical delivery are

40

4

Ibid. at 3.

lbid. at 1.

R.S.O. 1990 , c. C-20.

Over-The-Counter Derivatives and Companion Policy 91-504CP (2000), 23 O.S.C.B. 51.

Supra note 7.

Ibid. at $\$ 6(a)$.

Ibid. at $\$ 1 \mathrm{l}(11)$.

See CFTC, Re Competetive Strategies for Agriculture Lid., CSA Investor Services Inc., Lee Donald Amundson (24 August 1998), 98-4 at 5, online: CFTC <http://www.cftc.gov/opa/enf98/opacsa 082498.htm>; Re Southern Thumbs Co-op Inc. (7 October 1999), 97-3, online: CFTC <http://www. cftc.gov/enf/99orders/enfsouthernthumb.htm>; "To Change or not to Change the CFTC Prohibition of Agricultural Trade Options: An Overview of Relevant Economic, Legal and Public Policy Factors," online CFTC <http://www.cftc.gov/opa/speeches/opadial-45.htm>; and "Testimony of John E. Tull, Jr. Acting Chairman Commodity Futures Trading Commission Before the Subcommittee on Risk Management and Specialty Crops" (24 July 1996) at 2-3, online: CFTC <http://www.cftc.gov. 
viewed as forward contracts. The CFTC has exempt certain transactions such as options trades by commercial users such as producers, processors, or merchants handling a commodity for purposes related to their business. ${ }^{48}$ Swaps are also exempt provided that (1) they are entered into solely by "eligible swap participants"; (2) they are not a part of a fungible class of agreements that are standardized as to their material economic terms; (3) the creditworthiness of the counterparty is a material consideration in determining the pricing, cost, credit enhancement, and other terms of the agreement; and (4) they can not be entered into and trade on or through a multilateral transaction execution facility. ${ }^{49}$

Since 1995 the Natural Gas Exchange Inc.("NGX") has carried on the business of providing an electronic system pursuant to which certain parties can trade futures contracts for the delivery of natural gas. Somewhat similar to the NYMEX, the NGX provides for the trading of a variety of different gas contract terms and delivery points. As well, it is generally intended that futures sellers deliver the natural gas pursuant to the terms of the futures agreement (i.e., without transportation basis risk). Given that the contracts trade on an exchange and that the counterparty is the NGX, these contracts would be viewed as futures contracts even though the intention to provide physical delivery renders them difficult to distinguish from forward contracts. As elusive as the distinction between these two characterizations of ordinary course supply contracts appears to be, it is an important one in Canada, given the manner in which these types of contracts are regulated.

\section{A. FORMS}

\section{Documentation}

OTC derivatives are documented through agreements many of which have been standardized to a large degree. They follow the general format of a specified master agreement, with individual transactions being detailed in confirmations that incorporate the master agreement by reference. Many of the derivative intermediaries, such as Enron and Koch, have their own form of master agreement which can be used for over-thecounter financial and commodity derivatives and forward sales. Natural gas sales agreements for gas traded at AECO " $\mathrm{C}$ ", for example, are generally documented according to the companies' master contracts which have, over time, become relatively standardized as to their terms and conditions. One issue that often arises when negotiating these gas sale contracts is the applicability and extent of a force majeure clause. While financial derivatives generally do not contain force majeure clauses, forward sale agreements may include some degree of force majeure exemption. Clearly, the level of force majeure in a natural gas contract that is to be traded similarly to a financial derivative instrument needs to be severely limited. Extensive force majeure clauses can be negotiated between the producer and ultimate buyer in a customized transaction. However, where the producer and the ultimate purchaser may never meet, the specific force majeure rights must be limited to events which affect both parties, such as a pipeline failure at the exchange point or some other inability to physically transfer gas to the buyer at the delivery point.

opa/speeches/opatull-14.htm> (all date accessed: I August 2001). See also NRT Metals Inc. v. Manhattan Metals (Non-Ferrous) Ltd., 576 F. Supp. 1046, 1050 (S.D.N.Y 1983). 
Wellhead to delivery point force majeure is difficult, if not impossible, to accommodate in such a standardized transaction.

\section{B. ISDA 1992 MASTER AGREEMENT}

Most OTC derivative contracts use the International Swaps and Derivatives Association, Inc. ("ISDA") form of contract. ${ }^{\text {so }}$ The contract consists of a master agreement, a schedule and a confirmation for the various transactions. Changes to the master agreement, elected options, and additional provisions are all contained within the schedule to the master agreement. The current ISDA form is the 1992 master agreement. For Canadian purposes there are two master agreement forms; namely, the multicurrency-cross border and the local single currency form. While the local single currency form is somewhat simpler, the multicurrency-cross border version is generally used for Canadian transactions because it allows for a wider range of transactions, including US dollar hedging.

The ISDA master agreement allows for a wide variety of transactions. However, it does so at the expense of agreement sophistication. One of the reasons that some parties avoid using the ISDA form of agreement in favour of their own forms of agreement is that the former is relatively awkward to tailor to a particular transaction.

The ISDA master agreement is essentially a bilateral credit agreement, ${ }^{51}$ and it features the following general provisions: general conditions relating to the various transactions; withholding tax provisions; provision for default interest; representations by both parties; specification of the events of default and termination; calculation of damages; assignment provisions; currency provisions; allocation of expenses; governing law; notification addresses and miscellaneous interpretation provisions. Some of the key provisions are examined below.

\section{NETTING}

Clause 2(c) of the master agreement provides that when, in respect of the same transaction and the same currency, both parties owe each other money, then the person owing the higher amount pays the other the difference. If the parties desire to net amounts in respect of more than one transaction, then they need to so specify in the schedule or in a specific confirmation.

Netting is distinguished from setting-off, which may become controversial when negotiating an ISDA form. While netting with respect to the same contract is efficient and non-controversial, setting-off is generally contemplated in a default situation and is effected against amounts payable from other contracts. While setting-off may provide certain cash flow efficiencies, if the agreement is permitted to include affiliates and other specified entities (by so specifying in the schedule), the process may open to set-off a wide variety of obligations some of which may not yet be due. 
Having an express right of set-off may give additional remedies in the event of the bankruptcy of a counterparty, unless the set-off was set up as a fraudulent preference. While there is no basic set-off language in the master agreement or schedule, the user's guide to the 1992 ISDA master agreement (1993 edition) provides language that can be incorporated by adding it to the schedule to the master agreement. ${ }^{52}$ Bearing in mind that the non-defaulting party may be required to make a payment to the defaulting party if the "second method" (explained below) has been elected for the calculation of required payments on a termination of the agreement, a set-off clause in such a situation, will provide the non-defaulting party with the significant advantage of being able to set-off from its payment any amounts already owned to it by the defaulting party. The downside to a set-off clause is that it may permit a party to withhold payment based on an unrelated or contentious claim which derogates from the primary intent of the master agreement to provide for swift and certain payments.

\section{GROSS-UP FOR TAXES}

If a Canadian oil and gas producer enters into an ISDA master agreement with a foreign counterparty, the producer may be faced with tax withholding obligations in respect of interest-bearing derivatives. ${ }^{53}$ Since derivative instruments are priced without consideration of taxes, the ISDA master agreement contains a mechanism by which the applicable party must gross-up its payments to put the counterparty in the same position as if there were no tax withheld. The taxing provisions are quite complicated and provide exceptions to the gross-up where there is a breach of a representation by the payee, or where the tax is imposed as a result of the payee having a connection to the jurisdiction imposing the tax. If there is a change in the law which necessitates a new withholding, then unless the payee breached the agreement or one of its tax representations, the payor remains obligated to gross-up the amount to be paid by the withholding amount. In such an event, however, the particular change in the law may be deemed a "tax event" in which case the agreement may be terminated.

\section{EVENTS OF DEFAULT AND TERMINATION}

Section 5 of the ISDA master agreement specifies certain default and termination events, while section 6 deals with the parties' rights and remedies in the event of early termination. Much of the schedule is dedicated to options and clarifications relating to these two sections, and the schedule can also be amended to customize these terms. The default and termination events are negotiated to effect a balance between the desire to incorporate appropriate incentives for performance, and the undesirable effects of terminating the agreement prematurely. Accordingly, significant time and effort will likely be spent by each party ensuring that it is satisfied with the creditworthiness of the other party to the transaction. Credit risk may be sufficiently reduced through a parental guarantee or other credit support device. issue. 


\section{a. Events of Default}

The ISDA master agreement allows the parties to identify specific entities and transactions where a default will be deemed to be a default of the agreement as a whole. Such specified transactions or parties would likely be those with which the counterparty has dealt, or parties who have provided credit support. Events of default in the agreement include normal and expected events of default such as: the failure to pay or deliver when required pursuant to a transaction; any other breach of the agreement; a failure in a credit support document; a misrepresentation; a bankruptcy or other insolvency event; or a merger that obstructs any one of the merged party's obligations, including credit support obligations.

The parties can also choose to include a cross-default provision. The cross-default provision, must be elected in the schedule to be effective. This provision merely specifies a cross-default as between the parties to the contract if any default occurs in respect of borrowed money, provided that the amount of the borrowed money is in excess of a threshold amount. The threshold amount is negotiated and then specified in the schedule as either a dollar amount, or a percentage of a party's equity. In the schedule, the parties can expand the cross-default mechanism so that a default could be triggered by a default of any other specified entity such as, affiliates of the party (credit providers being included in the 1992 version without having been specified). The cross-default provision can be expanded beyond defaults relating solely to borrowed amounts. As well, the parties can identify the types of indebtedness or a specific indebtedness in respect of which a default would also cause a default under the ISDA master agreement.

\section{b. Termination Events}

In addition to "events of default", there are "termination events" which trigger different remedies. Termination events are essentially "no fault" events that include the following: illegality (i.e., where a law changes, rendering any transaction unlawful or preventing a credit supporter from performing its obligation); a tax event which results in a gross-up amount having to be paid or a new withholding tax to be withheld (as mentioned earlier in this article); and a tax event which arises upon the merger of either of the parties. In addition, if so elected by the parties to the agreement, a merger of a credit support provider can be treated by the other party as a termination event if the creditworthiness of the resulting entity is materially weakened by the merger. The parties are also free to specify additional termination events in the schedule.

Where a termination event occurs, a party may terminate the transaction subject to its right to attempt to transfer the agreement to avoid the termination event. However, any such assignment would be subject to the consent of the other party. On the occurrence of such a termination event, the transaction will be terminated on the date designated which shall not exceed twenty days after notice is given by one party to the other. 


\section{REMEDIES}

\section{a. Termination Event}

In the event that only one party is affected by a termination event, the unaffected party must calculate its resulting losses or gains on the basis of either (1) market quotes, if that method was elected and is feasible, or (2) the loss of bargain or cost to replace the unaffected transaction, adjusted for any amounts owing by one party to the other. If the unaffected party accrues a net loss, then the affected party will pay the unaffected party the amount of such net loss. If the unaffected party accrues a net gain, such gain will be paid by the unaffected party to the affected party. In the event that both parties are affected by the termination event, the parties will share the loss or gain by each calculating its respective loss or gain, and the party with the lowest loss or highest gain pays the other party half of the difference between the two parties' calculated outcomes (i.e., making a net payment).

\section{b. Event of Default}

If the termination arose as the result of an event of default, the applicable remedy will depend on the elections of the party as set forth in the schedule to the master agreement. The parties can elect that the "first method" or the "second method" will apply and that either the "loss" method or the "market quotation" method will apply. The "loss" method requires the non-defaulting party to calculate its losses and costs (or gain, in the event of a negative loss) resulting from the termination of the transactions which includes "any loss of bargain, cost of funding or, at the election of such party but without duplication, loss or cost incurred as a result of its terminating, liquidating, obtaining or re-establishing any hedge or related trading position (or any gain resulting from any of them). ${ }^{154}$ The "market quotation" method requires the non-defaulting party to obtain a market quote for the terminated transaction if one is available, and to calculate the loss if a market quote is not available for the terminated transaction.

The "second method" requires the non-defaulting party to pay to the defaulting party any gain it might achieve as a result of the early termination, contrary to the "first method" which does not require such gain to be disgorged. Unless the parties specify otherwise, the "market quotation" and the "second method" apply by default. Any resulting amount payable by one party to the other is subject to any set-off that is specified in the schedule or otherwise permitted at law.

\section{CONFIRMATIONS}

Clause 9(c)(ii) of the master agreement provides that confirmations in respect of each transaction may be made orally, by fax, or by exchange of electronic messages on an electronic messaging system. Many parties amend this provision because enforcing or approving a transaction that has only been agreed to by a telephone call between the traders may be difficult for evidentiary reasons, particularly because of the Statute of 
Frauds ${ }^{\text {ss }}$ which requires that an agreement over a term of one year be in writing. While many parties agree in the schedule to permit the taping of conversations (as a result of American laws on the point) which would assist on the evidentiary issue, such a mechanism may still not satisfy the requirements of the Statute of Frauds. It appears to remain an open question whether, absent pending legislation addressing this issue, messages by e-mail as provided for in the master agreement would satisfy this requirement.

In any event, parties generally specify the manner in which confirmations are to be approved. One clause that is found in a number of agreements provides that, while the parties intend to be bound from the moment that the transaction is agreed to by telephone, the terms of the transaction are not legally binding until such time as the written confirmation is approved in the manner specified. This method requires a confirmation to be approved by a specific officer who is not the same person as the trader, and functions to prevent rogue trading.

\section{FORM OF SCHEDULES AND CONFIRMATIONS}

\section{a. Schedules}

As discussed above, the standard ISDA schedule to the master agreement provides an outline of options that may be agreed to in the master agreement. In addition, parties specify in the schedule: notification particulars; additional tax and other representations; additional termination events; corporate authority documents which are required to be provided by each party to the other (which may include such documents as bylaws, articles, execution and enforceability opinions, tax forms, or certificates); selection of governing law (the law of the State of New York being the ISDA default) and so on.

\section{b. Confirmations}

The confirmation merely sets out the deal particulars, and uses the 1991 ISDA definitions if it is a financial transaction or the 1993 ISDA Commodities Derivatives definitions if it is a commodities transaction. ${ }^{56}$ These definitions identify specific references for price, rate, yield and other relevant indices. Occasionally a confirmation is executed prior to the master agreement being finalized, in which case, the confirmation will provide more detail and will generally specify that the 1992 ISDA master agreement applies with the elections set forth in the schedule to the confirmation until such time as a parties negotiate the master agreement.

\section{BANKRUPTCY AND INSOLVENCY}

As mentioned above, the creditworthiness of each party to an OTC derivative transaction is critical since pricing generally does not take into account credit risk.

1991 ISDA Definitions (New York: International Swap and Derivatives Association, Inc., 1991); 1993 ISDA Commodity Derivatives Definitions (New York: International Swaps and Derivatives Assocation, Inc., 1993). 
Further, the transactions are set up in such a way that amounts owing between counterparties can be netted, and in a default or bankruptcy-type situation, the transaction can be terminated to prevent any losses to the non-defaulting party from escalating. The ISDA has prepared a model netting act and has been working with national governments around the world to enable a global regime which permits a netting off of obligations at the termination of a derivative contract, notwithstanding the ordinary consequences of bankruptcy or insolvency. Not coincidentallythe definition of "eligible financial contract," incorporated into the Bankruptcy and Insolvency $A c t^{57}$ pursuant to revisions of the Act in 1992 and included in the Companies Creditors' Arrangement Act ${ }^{58}$ in 1997, is almost identical to the definition of "qualified financial contract" in the ISDA model netting act. Eligible financial contracts are defined in both Canadian statutes as meaning:

(a) a currency or interest rate swap agreement,

(b) a basis swap agreement,

(c) a spot, future, forward or other foreign exchange agreement,

(d) a cap, collar or floor transaction,

(e) a commodity swap,

(f) a forward rate agreement,

(g) a repurchase or reverse repurchase agreement,

(h) a spot, future, forward or other commodity contract,

(i) an agreement to buy, sell, borrow or lend securities, to clear or settle securities transactions or to act as a depository for securities,

(j) any derivative, combination or option in respect of, or agreement similar to, an agreement or contract referred to in paragraphs (a) to (i),

(k) any master agreement in respect of any agreement or contract referred to in paragraphs (a) to (j),

(I) any master agreement in respect of a master agreement referred to in paragraph (k),

(m) a guarantee of the liabilities under an agreement or contract referred to in paragraphs (a) to (l) or (n) any agreement of a kind prescribed. 59

If a transaction is included as an eligible financial contract, then, notwithstanding the terms of the Bankruptcy and Insolvency Act and the CCAA, the non-defaulting party can exercise its rights under the termination and netting-off provisions rather than giving an option to the trustee in bankruptcy, or to the company that is subject to CCAA proceedings, to pick and choose those transactions with which it wishes to continue.

However, the distinction between "ordinary supply contracts" (forward sales agreements) and "futures contracts" (by which the parties generally do not intend to settle by physical delivery), has been held to be a factor in determining whether or not a given contract is an "eligible financial contract."

In Re Blue Range Resources Corp. ${ }^{60}$ the Alberta Court of Queen's Bench refused to treat two master gas purchase agreements as eligible financial contracts. The issue was

R.S.C. 1985 , c. B-3, as am. by Bankruptcy $A c t, 1992$, c. 27 , s. 30(8).

R.S.C. 1985, c. C-36, as am. by Bankrupicy and Insolvency Act, 1997, c. 12, s. 124 [hereinafter CCAA].

CCCA, ibid. at s. 11.1(1).

(1999), 245 A.R. 172 (Q.B.), [1999] A.J. No. 830 (Q.B.), online: QL (AJ). Overturned on appeal, infra note 66 [hereinafter Blue Range]. 
whether these agreements were master agreements in respect of "a spot, future, forward or other commodity contract." The monitor and the secured creditor of Blue Range Corp. argued that, if these particular contracts were construed eligible financial contracts, the stay provisions of the $C C A A$ would become meaningless. Justice LoVecchio, therefore, began his analysis with the question of whether these master agreements were financial in nature, or were simply supply contracts. If the agreements were financial in nature, then they would be eligible for court protection, but if not, they were simply supply contracts. The Court focused on the word "financial" in the term eligible financial contracts and determined that the question was whether the contract was intended to be in essence a financial or physical contract. This test is similar to that used to determine whether a contract for the future delivery of commodities is a futures contract or a forward sale. It is respectfully submitted that whether the contract provides for physical delivery may be a factor, it should not be the exclusive determinant, as it seems to have been decided by the Court.

The master agreement used by Enron in this case, which was not an ISDA form, commenced with the following words: "WHEREAS, Customer (this is Blue Range) and ECT Canada (this is Enron) may from time to time enter into firm natural gas purchase and sale transactions." 61 From this wording, the Court determined that the contracts were physical in nature as opposed to financial, and consequently that they were not eligible financial contracts.

The Court stated that the 1992 ISDA master agreements are eligible financial contracts:

It is not disputed that the ISDA Master Agreements are "eligible financial contracts". These agreements follow the form of the "1992 ISDA Master Agreement". This agreement is the standard form agreement developed by the International Swap Dealers Association, Inc. [sic, since 1993, the International Swap and Derivatives Association, Inc.] for the governance of a broad variety of derivative transactions. One of the principal features of all the ISDA Master Agreements is the ability of the parties to elect to "net out" their payment obligations on several separate transactions. ${ }^{62}$

However, the 1992 ISDA master agreement, unlike the 1987 version, ${ }^{63}$ specifically contemplates physical delivery. While many companies do separate their physical delivery contracts from their purely financial contracts, there are a number of ISDA master agreements being used for both physical delivery and non-physical delivery transactions. Furthermore, there are a number of different transactions entered into for financial hedging purposes which nonetheless contemplate physical delivery. Lastly, the definition of "eligible financial contracts" does not appear to exclude physical transactions because it expressly includes spot, forward and future commodity contracts. It is unfortunate that the Court did not attempt to reconcile these significant inconsistencies.

Generally, the primary purpose of a producer entering into derivative contracts is to hedge against declining prices and to provide financial certainty. The producer being

(2) Ibid. at 178 , para. 40.

6.3 1987 ISDA Master Agreement (New York: International Swaps and Derivatives Association, Inc., 1987). 
naturally "long" in the commodity, and end users being naturally "short" in the commodity, each hedges the commodity in opposing ways to reduce its risk of unfavourable volatility. The producer can either buy put options, or it can sell futures on an exchange. Futures traded on some exchanges, the NYMEX for example, require physical delivery unless they are closed before expiry by an offsetting trade. While futures are generally closed before maturity by an opposing trade, this is not always the case, therefore, there are specific procedures in place for physical delivery of the Underlying.

A producer of oil or gas is essentially indifferent as to whether it is required to actually deliver a physical supply of the commodity, or whether it is required to close out the transaction in cash. The result to the producer is the same in both cases. It has hedged the price of its production. This equivalence of outcomes applies equally to the end user, which may either enter into a long-term contract to hedge the price of the oil or gas that it will need to purchase in the future, or it may buy on the spot market and enter into financial transactions to give it the same hedging effect. Either way, the value at any given time of a forward contract or futures contract will depend on the fluctuating spot price of the underlying commodity.

The hedging feature of physical delivery contracts is even implicitly acknowledged by the Alberta Securities Commission ("ASC") in its Order governing the Natural Gas Exchange. A hedger is defined as a "person or company who... as a necessary part of [certain] activities, becomes exposed from time to time to a risk attendant upon fluctuations in the price of gas and offsets that risk through trading in gas contracts..."64 Given that natural gas contracts on the exchange expressly provide for the physical delivery of natural gas and that such natural gas is generally delivered, hedging activities clearly encompass physical transactions in the view of the ASC.

Furthermore, the marked-to-market value, be it positive or negative, of a derivative instrument or product depends on the spot price of the Underlying at the time. The spot price of a commodity can change significantly over the life of the derivative. If the nondefaulting party is required to continue fulfilling its obligations under a derivative contract after the other party is no longer able to meet its obligations, its losses can grow (sometimes exponentially) if prices are going against it. Ordinarily, the non-defaulting party will fix its losses and gains by entering into a further hedging arrangement to prevent further losses. The eligible financial contracts exceptions in the CCAA and the Bankruptcy and Insolvency Act permit the crystallization of the marked-to-market value of the derivative and allow the non-defaulting party to enter into such further derivative transactions as are necessary to avoid further losses without having to predict whether the bankrupt or insolvent will ultimately fulfil its obligations under the transaction.

In a forward sale, the credit risk involved is the same whether or not physical delivery at maturity is contemplated. A hedge on oil prices by entering into a forward contract is no less a financial transaction than the sale of oil futures on NYMEX. The Alberta Court of Queen's Bench in Blue Range decided that, because the parties intended to deliver the 
physical commodity, the contracts were not financial in nature. ${ }^{65}$ The decision was overturned on appeal. ${ }^{66}$ The Court of Appeal unanimously determined that eligible financial contracts include both physically settled and financially settled transactions. The Court identified that the definition of eligible financial contracts included spot contracts, spot foreign exchange contracts and repurchase or reverse repurchase contracts which can only be settled by physical delivery and not by financial payment. The Court also indicated that there was no evidence of ambiguity in the meanings of an eligible financial contract or foreign commodity contract:

Nor is there ambiguity in the expressions "eligible financial contract" or "forward commodity contract" to justify defining either term by reference to physical or financial settlement. It is only when a statute is fairly capable of two constructions that words of qualification can be used to resolve the established ambiguity or imprecision: Howley v. Canada (Deputy Attorney General) (1976), 69 D.L.R. (3d) 689 at 695 (S.C.C.). It is not necessary to require financial settlement in order to inpart meaning on s. 11.1 (1)(h); these contracts are risk management tools and serve a financial purpose unrelated to settlement. The presumption of straightforward expression also obliterates the physical and financial settlement distinction. The term "forward commodity contract" is included in the section without any words of qualification. ${ }^{67}$

The argument raised was that by including physical contracts, the purpose and intent of the CCAA would be lost. However, the important distinction to be made was in the meaning of commodity. The Court of Appeal referred to the Oxford English Dictionary Second Edition definition which would include any "thing produced for use or sale... article of commerce... [or] object of trade" 68 which, if this definition were used, would indeed include almost any physical contract and would severely restrict the ambit of the $C C A A$. However, "commodities," as used in the derivatives markets, are restricted to items which are fungible or easily interchangeable and which have no specific unique characteristics. As mentioned earlier, this includes most of the products of an oil and gas company. It is a fact that the underlying commodities are fungible which allows the commodity exchange markets to operate. A person who takes delivery of oil at Cushing, Oklahoma of a certain grade, cares not about who produced that oil or from where it was produced. Likewise, an oil and gas company can readily find markets for its products by selling on a spot market. It is interesting to note, however, that while natural gas is a fungible commodity, the ability of a western Canadian oil and gas company to sell its gas has not always been as easy as it is today due to transportation and market restrictions, and there have been times when the ability to sell one's gas has been very much a significant value.

In any event, the Court of Appeal quoted with approval a definition of a forward contract for the energy industry as:

The contracts' specific terms were not assessed in the Court's characterization of the contracts as normal supply contracts rather than financial hedging transactions. The Court appears to have simply concluded that an expression of intention to effect physical delivery necessarily precludes characterization as a "financial transaction." Re Blue Range Resources Corp., (2000) 266 A.R. 98 (C.A.); [2000] A.J. No. 1032 (C.A.), online: QL (AJ). 
A customized contract to buy or sell a commodity for delivery at a certain future time for a certain price. It is customized by individual negotiations between two parties, rather than standardised and traded on a board of trade. The parties to the forward contract usually know each other, and in most cases the contract is settled by actual delivery of the commodity."

and identified the following key elements of a forward commodity contract as including:

(a) buyer of natural gas;

(b) a seller of natural gas;

(c) a defined contract term longer than the next day;

(d) a defined volume of natural gas;

(e) a defined delivery and receipt point (including any transportation requirements, as applicable); and

(f) a defined price or pricing mechanism."

The Court of Appeal has given certainty to the question of the meaning for forward commodity contracts for the oil and gas industry and this clarity should permit greater financial options to oil and gas companies in Alberta.

\section{TAX}

While there is limited jurisprudence on the income tax consequences of derivatives, the position of Revenue Canada with respect to commodities and futures is that taxpayers who enter into futures positions as part of their business operations will receive income treatment in respect of the gains or losses (i.e., profits will be fully taxable as income and losses fully deductible from income). Likewise, corporations whose primary or only business activity is trading in futures will also receive income treatment. However, a speculator will receive capital treatment only when (1) speculation is his prime or only activity, and (2) he consistently uses that same method of reporting. However, Revenue Canada recognizes that there may be a taxpayer that takes hedging positions in respect of its business but also speculates in the market by taking derivative positions in excess of the amount of commodity which is consumed or produced (as applicable) by his business. In such a case, income treatment will only apply to the portion of the Underlying that is reasonably attributable to the business."

\section{CONClusion}

This has been a necessarily general overview of derivative instrument transactions applicable to oil and gas producers. There is no limit to the variety of hedging products and trading strategies that can be designed and entered into. Consequently, new products and intermediaries are emerging frequently. In western Canada, the market for natural gas forward contracts is expanding with a number of on-line electronic trading sites that have

Ibid. at 112, para. 48. Fruman J.A. quoting Haedicke \& Aronowitz, "Gas Commodity Markets" in Energy Law and Transactions, vol. 4 (New York: Matthew Bender, 1999) 88:19 at 74-75.

Supra note 66 at 113, para. 49 citing the expert report of James Joyce.

See M.N.R., Interpretation Bulletin IT-346R, "Commodity futures and certain commodities" (20 November 1978). See also D.F. Sykora, "The Income Tax Web Surrounding Derivatives" (1995) 30:1 Can. Tax Found.; see also E.A. Heakes, "The Income Tax Consequences of Using Derivatives for Hedging Purposes" (1995) 8:1 Can. Petroleum Tax J. 109. 
been recently introduced, or are currently being introduced. Commodity futures permit the acquisition of rights in a commodity without actually owning the commodity, and they allow parties to significantly leverage changes in the price of the commodity. Most importantly, derivative products enable oil and gas producers to actively manage non-core business risks such as depressed commodity prices, high interest rates, and unfavourable currency exchange rates. 